\title{
Radical Islam as a Means of Self-Realization for the North Caucasian Youth: From the Terrorist-Criminal Groups to the Beginnings of the Creation of a New, Less Controlled Subculture
}

\begin{abstract}
Radical Islam with its various types of manifestations is one of the significant challenges facing the modern world. This problem has also affected the societies of autonomous republics bordering Georgia to the north. In today's North Caucasus, the activity of radical Islam followers has reached beyond the political (in many cases terrorist) niche and has acquired quasi-social characteristics. Furthermore, the facts and tendencies indicate that this part of the society (in this case youth) purposefully or unintentionally creates the so-called uncontrolled and/or less controlled subculture with different opinions, views, ideology, behaviors, in many cases clothes, hairstyle, etc. Radical Islam (in this case as a doctrine) regulates human conduct - provides advice, dictates how to act, and in fact it sets a dogma how to dress, how to behave in public, how to live, etc. Wahhabis/Salafis are forbidden to smoke tobacco, hashish, to use beads, sing loudly, dance, etc. It is worth to separately note the so-called aggressive wing of Wahhabism/Salafism or the terrorists, field commanders, etc.

One of the motives for writing the article is to show readers the fact that radical Islam in North Caucasus is not solely a terrorist activity. It encompasses a much broader spectrum of the society, and at the same time it is much more than a religion. It sets the norms of social behavior and thinking, which in itself limits the formation of subjective attitudes. Exactly the lack of the latter generates the negative trend of their activities, which quite often are used for political actions by the respective forces.
\end{abstract}

Keywords: North Caucasus, Russia, Wahhabism, terrorism, radical islam, subculture

\section{Introduction}

As a result of social-economic problems that arose in the early 1990s in North Caucasus (following the dissolution of the Soviet Union and Chechnya-Russia wars), a certain part of the society became engaged in illegal activities (e.g. military or terrorist activities, preaching forbidden religion, calls for a holy war, etc.). In particular, as a counterbalance to the unemployment and the impossibility of 
self-realization a Sunni Islam's aggressive wing has emerged, which turned out to be very attractive for the population (it was existing previously as well, though drawing less attention of the youth).

The creation of Wahhabism as a religious and social-political movement is connected to Mohammed ibn Al-Wahhab, who lived on the territory of Saudi Arabia in the first half of the $18^{\text {th }}$ century. However, Wahhabism was especially spread in North Caucasus in the 1990s, which was largely the influence of the visits and preaches of the emissaries, sheikhs, etc. from Arabic countries.

The article describes the life of radical Islam followers, tendency of their formation as a less controlled subculture, current situation, driving factors of the youth joining this subculture and their activity, causes of development and popularity of radical Islam, problems connected to it, policy of central and local authorities towards prevention of the problem, etc.

Various electronic resources, assessments of the experts working on the North Caucasus issue, opinions of the researchers studying the modern state of Islam, and the news reported on this issue during the last two-three years have been used for working on the article. Therefore, the author provided an analysis of the information and identification of the tendencies.

The article is intended for those readers, who are interested in the analysis of the ongoing processes in North Caucasus, for persons, who are interested in studying the problems connected to radical Islam, and also for that part of Caucasiologists, who work in the field of humanitarian and political sciences.

The essence of the article is more or less already captured in the title. However, one important point should be taken into consideration: the classification in time and space of the main actors of the article is conditional, their belonging to the so-called subculture is conditional as well, given that radical Islam followers do not exist as a classic type of subculture. There are in the so-called transitional phase, when a person due to his/her inner characteristics can be attributed to the subculture in a particular period, but later the person may become a classic terrorist and/or criminal or become a follower of radical Islam's moderate wing (it should be noted that a person belonging to the subculture very rarely returns to the quiet rhythm of life or to the way of life before joining the subculture). The issue of characteristics which a person should have in order to be attributed to the subculture will be discussed below. 


\section{Radical Islam as a Means of Self-Realization for the North Caucasian Youth (from the Terrorist-Criminal ${ }^{*}$ Groups to the Beginnings of the Creation of a New, Less Controlled Subculture)}

Radical Islam ${ }^{1}$ is one of the serious challenges facing the Russian Federation. It creates not only a negative trend of political events for the state, but it also contradicts the traditional and legal elements existing in the largest part of the Russian Federation. The radical Islam movement does not represent a problem only in terms of security. It generates a long chain of social and humanitarian events, which is manifested in particular resonant facts, as well as in the fact that in the medium and long-term perspective new groups (not only terrorist-criminal) and also a new quasi-social, less controlled environment similar to subculture are likely to be formed. In this new subculture a decisive role is played by those youth, who represent the so-called radical Islam followers. Development and prospects of the latter mostly will depend on the Russian Federation state policy (social, as well as power politics), i.e. how much it will allow its metastasis to grow freely in mental and social depths of the society.

Radical Islam is mostly spread in Muslim dominated territories, especially in North Caucasus ${ }^{2}$, and Bashkir and Tatarstan republics ${ }^{3}$. The fundamental religions and the so-called sub-religion or sub-sect of followers live in North Caucasus. Most of the people are Sunni ${ }^{4}$ Muslims; however there are some Shiites ${ }^{5}$,

* The term "terrorist-criminal" exactly denotes the present situation of the aggressive wing of radical Islam followers, which is discussed below in detail.

${ }^{1}$ Radical Islam implies adherents of Salafism as well as Wahhabism, http://islam-today.ru/radical-movements/

${ }^{2}$ Geographical North Caucasus is much bigger than the North Caucasus Federal district. It includes: Dagestan, Chechnya, Ingushetia, North Ossetia, Kabardino-Balkaria, Karachay-Cherkessia, and Stavropol region.

${ }^{3} \mathrm{http} / /$ www.ansar.ru/analytics/v-tatarstane-preduprezhdayut-ob-ugroze-radikalnogo-islama.

4 The word Sunni comes from Arabic word "ahl as-sunnah" which means adherents of Sunni. Sunnism was started in the Arabian Peninsula in the seventh century. In the modern world almost $90 \%$ of Muslims are Sunni adherents (1.5 billion). Sunni is spread in: Turkey, the Russian Federation, most of the Arabic states, etc. Sunni adherents are divided into several main groups and sects: Sufism, Alafism, Wahhabism, etc. There are 4 traditional schools of law (the so-called "Mudhhub"): Hanafi, Shaf' ite, Malikite, and Hanbalite. In the region Sunni developed gradually, monadic trades played the biggest role for spreading the religion over the territory, as they chose this location for their deployment.

5 Shiites represent one of the biggest denominations of Islam. It is spread in Iran, Azerbaijan, Syria, and in other countries. Braches of Shia Islam are: Druze, Ismailis, and Zaidis. Sunni-Shia split occurred after Islamic prophet Muhammad died and Shia chose Muhammad's cousin as his successor, while Sunni belived in Caliphates. http://relig.info/encyclopedia/shiizm 
especially in Dagestan. Additionally, the Sunni adherents in the region are divided into two groups: the so-called "Traditional" and "Puritanical" Islam followers". Nowadays, conflicts mostly arise between traditional and puritanical Islam adherents. Conflicts usually occur as fights, murders, kidnapping, and intimidation. In the last 10 years over one hundred religious leaders (Mullah, Sheikh, Mufti, etc.) and civilians died because of those conflicts?

\section{Classification of Radical Islam Followers (Adherents): General Information}

It is very complicated and vague to classify Radical Islam followers in the North Caucasus. The Russian media divide Wahhabits into reformers and radicals (it should be noted that it is wrong to amalgamate both cultures into a new subculture). The main aim of both cultures is Islamization ("Radicalization" would be more correct) of the whole region (and not only this region) and establishing a united state ruled by the Sharia law. The reformers believe preconditions are needed in order to spread Wahhabism, like the strategy for the next 20 years and substantial strong propaganda and advertising. Propaganda includes massive construction on mosques, public distribution of brochures and literature, active support for Wahhabism using various means like missionary work, etc. On the other hand, the abovementioned is not enough for Radical Wahhabis and they demand aggressive military action. The majority of Wahhabism adherents consider themselves Salafists, which makes it more difficult to classify Sunni Muslims. Historically, Wahhabism originated from Salafist scholar Muhammad ibn Abd al-Wahhab's teachings in the eighteenth century. Only later a more aggressive Islamic movement was formed on its basis. In the mid-20 ${ }^{\text {th }}$ century Salafists started their first activities in North Caucasus. However they have not shown active anti-government and/or anti-ideological movements during that time due to the absolute control and pressure of the Soviet Union. Radical Islam, the so-called "Puritanical", adherents can be divided into three categories (groups were formed according to author's subjective assessment of reality) ${ }^{8}$ :

\footnotetext{
${ }^{6} \mathrm{http}: / / \mathrm{cpnc} . r u /$ index.php?option=com_content $\&$ view=article $\&$ id $=346: 2012-07-25-05-51-$ 20\&catid=31:general\&Itemid $=46$.

7 http://www.start.umd.edu/sites/default/files/files/publications/br/STARTBackgroundReport_TerrorismAndNorthCaucasus_April2013.pdf.

${ }^{8}$ N. Chitadze, Main Aspects of Terrorism and Extremism in the North Caucasus Region, Journal of Social Studies 2013, Vol. 2, no. 1, pp. 5-10.
} 
a. Muslims, who live a normal social live and try not to violate religious codes. They do not promote religious dogmas. Their number is very small and they have very little or sometimes no influence over the youth.

b. Muslims, who are engaged in propaganda for Wahhabism (openly or underground) but do not encourage their followers to fight. They do not participate in military actions and only engage in propaganda. According to the Russian media and press, it is hardest to forecast the future actions of such people as there is a very thin border between preaching for Wahhabism and starting radical actions. In the long term, this group is expected to receive and set in motion the biggest number of young people. This group forms the least subordinating subculture, which is the most acceptable group for the Russian unemployed youth. The term subculture implies only specific people who meet the following criteria: a person must be a "Puritanical" and not "Traditional Islam" Sunni Islam adherent, comparatively aggressive, but not engaged in military actions, his appearance must be different from the others (beard, haircut, and clothes), he must be religious (attending prayers, reading Quran), he must know or must be studying Arabic language, he must have visited Arabic country or must be trying to go there for studies, his daily life must be in accordance with Quran suras, he must be familiar with imams' lives, he must strictly follow religious dogmas in relationship with the opposite sex and in consumption of alcohol or drugs, he must be inclined for the underground activities (the last requirement is not certain and depends on how active the person is), etc. The group unites not only the young people who live in the countryside but also people who live more or less peaceful lives. For example: they create websites with attractive slogans and Arabic emotional songs, and they "advertise" phrases from Quran in the Arabic language. Furthermore, they help materially and also engage physically (the so-called "wood rebels"). We should also pay attention to the fact that not only Muslims are the group members. Nevertheless, orthodox Christian ethnical Russians have taken their side. These facts indicate that their loyalty and full support to the "pseudo-culture" or/ land subculture is complete.

c. Rebel radicals actively encouraging Muslims to physically destroy "in the name of Allah" all who oppose the creation of the united Muslim state ruled by the Sharia law. Moscow considers all of them terrorists, as they are the main opponents of the central government. The youth is easily (quickly) drawn towards them. This happens first of all due to emotional factors and secondly due to financial factors. 
Emotional factors - the youth is able to realize their aggression by fighting against their enemies (the weapons are more or less limited). It all adds to the North Caucasus people's tendency towards fighting and a special love for weapons. The impossibility of self-realization and existing external environment (information vacuum) where they are raised causes their aggression".

Financial factors - as an encouragement after few "tasks" youth receive solid amounts of money (the first encouragement occurs after 1-3 months or/and before a serious task). A solid amount of money is the amount they would have worked for years to accumulate in civil life. The lives of these people are always under a great risk. However, they believe in rightness of their work and they love it (it is not only their responsibility but they need it). For them, the prize (in this life and in life after death) is worth their lives ${ }^{10}$.

\section{The Reasons for the Rapid Spread of Radical Islam Among the Youth (Reasons Why the Youth Chooses to Become Members of this Subculture and for Their Actions)}

The rapid spread of Radical Islam among the youth is mainly due to the following factors:

1. Social and economic factors. The social and economic conditions are very difficult in North Caucasus. Informally, one third of the work force is unemployed. The state transfers for public welfare are not properly used (60\% of transfers are used for corruption deals). It causes a negative background in the region. The data is not the same for different countries. In addition, the (financial) gap between the upper class and others is quite big. With all of the abovementioned, Radical Islam is the most important, even the main source for social justice and income ${ }^{11}$.

2. Irrational religious policy of the central government or its non-existence (not even for the young people, we will talk about it below). In spite of several attempts from Moscow, the religious policy is still failing in North Caucasus. In the region, most of the clericals are disqualified due to their incompetence. The local population accuses them of corruption and se-

${ }^{9}$ R. Borum, Psychology of Terrorism, Tampa 2004.

${ }^{10}$ M. Siddhartha, Three Essays on the Economics and Finance of Terrorism, 2007, http://www. gipe.ac.in/pdfs/working\%20papers/wp10.pdf.

${ }^{11}$ V. Dzutsev, Moscow Likely to Choose Control of Territories Over Their Economic Development, Eurasia Daily Monitor 2015, Vol. 12, Iss. 80. 
cret connections with the government, etc. The young people who received knowledge in foreign countries (Arabic countries) appeal to the public with the subjects acceptable for them ${ }^{12}$.

3. Political Factors. Moscow states that the North Caucasus region is extremely vulnerable, and the existing difficult social and political situation is used by its enemies. Furthermore, the so-called third parties use Radical Islam adherents (especially young people) for their own interests. Central and local governments state that there are number of ways in which their enemies' policies are realized. This part of the population is considered one of the most important tools for this. Specifically, the young people who received knowledge in Arabic countries. They involuntarily create groups opposing the government and less controlled subcultures. They use international humanization organizations' grants, study programs, etc. to study abroad. After their return (most of the times they return) they start the realization of the received knowledge. For these there are two forms. 1) The young people who are members of the Islamic groups that openly or secretly promote Wahhabism, but do not encourage their followers to fight (they themselves do not participate in military actions but might have some experience in them). People with such a biography are extremely popular; below we will talk about it more. In addition, new generations of clericals are good public speakers and use diverse technologies to influence the public. They gain popularity by strict performance of all religious canons, exposing shortcomings of central and local governments and giving radical speeches against them. Also by demanding social equality and blaming the government for anti-Islamic movements, knowing Arabic language fluently (the last one is specially sensitive, as the young generation considers knowing Arabic and ability to read in Arabic language as one of the indicators of a person's wisdom), etc. 2) The young people who join the "underground" and start military actions against the government after return. They give more aggressive speeches. They are fewer in number but because of their activities' resonance they are more well-known. Uniting them in the subculture is not reasonable ${ }^{13}$.

4. Corruption of the local (partly central) government and absence of the state welfare thoughts in the public ${ }^{14}$. Both of them play a big part in promoting

${ }^{12}$ http://scepsis.net/library/id_1121.html.

${ }^{13}$ http://md-gazeta.ru/articles/obshchestvo/imarat_kavkaz_vmesto_epiloga/.

${ }_{14}$ А. Акпадшахов, ВАХХАБИТЫ - ДЖИХАД ПРОТИВ РОССИИ 2008, http://www. pravoslavie.ru/analit/global/vah.htm. 
Whahabism (we mean not only specific actions, but problems caused due to unprofessionalism). The last was stated by Medvedev during his visit in Dagestan in 2011. At that time Medvedev was President and his statement was a serious signal for the government workers, whose corruption supports the success of Radical Islam. Their support is shown by the following facts: failed antiterrorist movements, illegal trade of weapons with rebels, justification of guilty radicals by judges, promotion of illegal literature (mainly young people are promoting illegal literature as they want to prove loyalty to their leaders and that they are true adherents of Radical Islam. Also they are waiting for a chance to go to an Arabic country), etc. ${ }^{15}$

5. Datum "You are different". As we mentioned above, a part of the Russian society emphasizes that it is absolutely natural to treat different ethnic groups and religion followers unequally before the law within the same country. This part of society includes not only organized groups like skinheads, the movement "Russia for Russians" but also persons supporting inequality by various means. In the last 5 years (the period was chosen, because Russia is more stable at this time than in the nineties) tens of non-Russians became victims of this movement, especially the North Caucasians. All of the abovementioned gives one more reason to a North Caucasian young person to feel unwanted the Russian Federation. The radical agitators use these sentiments for their own ends and pull youth away not only from the state but also from the Russian society.

\section{The Role of Youth in the Virtual Organization of Radical Islam Followers}

Radical Islam is gaining popularity day by day and is expanding geographically in the Russian Federation. Even though preaching Wahhabism is prohibited by law in the region and probably, respective services are maximally trying to control the situation, propaganda of Wahhabism, distribution of agitation literature, etc., still there are many legal and illegal organizations, the ranks of which are being filled with followers of Salafism (Wahhabis). Although Caucasus Emirates represents (represented until 2013) the most influential and more or less organized structure (activity of which is also the most resonant).

\footnotetext{
15 F. Coene, The Caucasus: An Introduction, New York 2009.
} 
Caucasus Emirates' structural division is rather conditional. However, according to the Russian and Western mass media, Caucasus Emirates have some characteristics of a state such as:

1. Executive authorities;

2. Legislative authorities (the function is carried out by the Majlis Al-shura);

3. Judicial authorities (performed by the emirate's Qadi);

4. Also it has a union Mukhabarati similar to the law enforcement agencies ${ }^{16}$.

There were/are many young people in these structures, but it is noteworthy that they do not get high positions. Such positions are usually represented by relatively old fighters (35-50 years old) who have gained experience and fighting skills during the first and second wars in Chechnya.

Caucasus Emirates has five territorial units: Vilayat of Nokhchicho (Chechnya), Vilayat of Ghalghaiche (Ingushetia), Vilayat of Noghai (Stavropol, Krasnodar, and Sochi directions), and Kabardino-Balkaria and Karachaevo-Cherkessia Vilayats. None of them has or ever had a young leader. That is why a lot of experts stated in the media that young radical fighters represent a much more uncontrolled part for Moscow than the old field commanders with whom it was easier to find a common language and even do a "common job". For this reason, it is considered that involving/appointing young people on high positions of the resistance forces would be more dangerous for Moscow than it is currently.

The main purpose of the existence of the so-called virtual state is the creation of a united Caucasian Islamic state that will be governed by the Sharia laws. By formation of the organization, the ethnic separatism has practically ended in North Caucasian and the religion separatism has started. However, the developments of the last two years in the region have shown that, on the one hand, the religious separatism was not able to become a factor consolidating the existing forces. On the other hand, the aforementioned contradictory elements were scattered and became like terrorist-criminal groups, who are far away from fighting for religious and/or ethnic purposes ${ }^{17}$.

The old generation field commanders and radical Islamists accuse the young people of being the cause of emerging Александр Акпадшахов as they introduced a new lifestyle, which in many cases is unacceptable for the old generation. It is noteworthy that this criticism is caused more by the fact that the youth do not or hardly subordinate to the elders (presumably for the reasons of money and weapons distribution). This is definitely the actual reason for their contradiction

\footnotetext{
16 А. Квахадзе, Имарат Кавказ - структура и тактика, Тбимиси 10.01.2013.

17 С. Маркедонов, Северный Кавказ в глобальной политике, 20 сентября 2014.
} 
rather than the knowledge of dogmatic religion and/or the tactics of the fight for the common goal ${ }^{18}$.

\section{Involving Young People in Radical Islamists Groups (with Desire or Force)}

The number of Radical Islam followers (warriors and propagandist-preachers) was increasing owing to local youngsters. There were pre-existing plans for winning these people over, also many youngsters had interest in Wahhabism and wanted to participate in the organizations (it depended on what kind of fight they preferred, did they want to sacrifice for Alah in the so-called holly war or did they want to establish strict religion norms and make locals to participate in all activities. The environment is an important factor too, young people are under a lot of physiological pressure. The normal development of their minds is disturbed by aggressive elements around, living during the war from very early years, explosions, and dead people, Punitive detachments, appeals for fighting for Allah, financial problems, unemployment, and hunger, while, on the other hand, there is a small part of the society who are richer, have more perspectives, and are "happy".

Meanwhile, there are people who are popular because of their religion knowledge, "the correct way of life", own financial resources and weapons (it is a real bonus for the Caucasian people) - these kind of people were a much better example for youngsters, They also had some romantic-emotional longing toward this part. At the age of 18-22, going out in the woods, the training, the opportunity to go abroad, racketeering, drugs are a huge adrenaline, and so, some young people get involved in illegal activities.

Moreover, the aggressive Russian population (ethnic Russians) had a humiliating and discriminatory attitude toward people of other religions, ethnicity, and culture. Even though the Russian union had limited differentiation with these criterions, people in the north of Caucasus remember Russians' and Moscow's activities in the nineties. I mean military maneuvers, followed by huge sacrifices, and the activities of the so-called Russian subculture skinhead movement "Russia for Russians" that were carried out in the last twenty years.

People who were taught to become suicide attackers must be highlighted too. Their involvement was more specific and difficult than preparing an ordinary preacher or fighters. These people were chosen from the families whose members

${ }^{18} \mathrm{http} / / /$ lenta.ru/articles/2015/03/04/salafism/. 
died in fighting with the federal center or sacrificed because of their aggressive activities or became sacrifice because of unacceptable factors for the locals. Future suicide attackers were trained under psychological pressure and with the use of drugs. Uniting suicide attackers with potential subcultures is probably not correct. Followers of "clean Islam" were in contrast with almost all parts of the society. They were called Murdats (people who changed their "true religion" and became followers of another course of Islam or another religion) and Kefirs (confessors of other religions). Actually, they were fighting with everyone around (the intensity was different).

\section{Young Radical Islamists' Demographic Situation in the Region}

Nowadays, young radical Islamists' activities are most visible in Dagestan. Meanwhile, Wahhabis are active in North Caucasus too. Their special activity in Dagestan has some subjective-objective reasons. First of all, it was a social factor (diversity of ethnicity, culture, and religions). In this case, radical Islamists were being elements for uniting, and unlike the dominant ethnic classes they had a new opportunity for self-realization. Secondly, the open terminal with the "other world". We are talking about the Caspian Sea and geographical border of Dagestan with Azerbaijan. Military, as well as social-humanitarian activities are less stirring in Chechens as young radicals have less opportunities there. Even though there were some military fights during the Kadirov's despotic stewardship, their activities were a bit modest.

According to the Russian media, there are thousands of radicals in the region. Different information is spread about the exact number. Also, as it is already said, their classification is very difficult and this data may not reflect an objective reality. Uniting Salafists and Wahhabis with religious radical psalmists is very difficult, because some of them are Salafists but others are against this opinion. Exactly this is the biggest problem with classification.

Contradictions between followers of other religions and radical Islam take place not only in the north of Caucasus but in Tatarstan too, where traditional Islamic muffs and mullahs are oppressed. The spreading of Islam and export in the depth of the Russian Federation contains a serious threat to the Russian society. So, the restriction of religion policies is possible to be started by the Federation, and this will be followed by serious problems and difficulties.

Moscow has established some international and local departments, ministries, and special groups for working with young people. Millions of rubles, human 
resources and time are spent, but due to some reasons, they have not achieved the desired results in the specified time. The first reason is the political system of North Caucasus and the second reason are social factors. Both of them are subject to research and cannot be discussed in the article.

\section{Conclusion}

Problems with radical Islam include political as well as humanitarian factors, so it is the most important challenge for Moscow. It is clear that Wahhabism is against the national interests of the Russian Federation and no activities directed against it have shown any results.

It should be highlighted that radical Islam is a much more serious problem for North Caucasus than terrorism and/or criminal activity (Russian experts, as well as European ones agree with this opinion). It is one of the most important things for the social-psychological existence of a society, when an absolutely strange for the state and local people, not adapted and not well enough controlled social union or subculture is created. And it counteracts local law, social-cultural norms, etc.

Popularization of radical Islam and the existing pace of involving young people in it will continue with high probability. "Balancing" of this trend is only possible with the implementation of correct humanitarian politics by the state. But metastases are so deep in people's minds that a complete elimination is almost impossible in the future twenty years. Meanwhile, if the social-economic environment is improved in the region and discrimination of religions, ethnicity, etc. becomes a thing of the past, the society and the state can be sure to achieve better results. 